\title{
Kırıkkale ilinde buğday ve arpa ekim alanlarında görülen fungal yaprak hastalıklarının belirlenmesi ${ }^{1}$
}

\section{Hacı Yunus ÖZDEMIR ${ }^{2}$ Aziz KARAKAYA ${ }^{3}$ Arzu ÇELIKK OĞUZ ${ }^{3}$}

\author{
ABSTRACT \\ Determination of fungal leaf diseases in wheat and barley fields of Kırıkkale \\ province, Turkey
}

In this study, leaf diseases occurring on barley and wheat fields in Kırıkkale province were determined. Survey studies were carried out in central province and eight districts of Kırıkkale in 2015 and prevalence and severity of diseases were determined. A total of 300 fields consisting of 128 barley and 172 wheat fields inspected. The following barley disease causing agents were found: Drechslera teres f. maculata, Drechslera teres f. teres, Drechslera graminea, Rhynchosporium commune, Erysiphe graminis f. sp. hordei, Puccinia striiformis, Puccinia hordei and, Puccinia graminis f. sp. tritici. Mean prevalences of these diseases were determined as $5.63 \%$ for $D$. teres f. maculata, as $1.77 \%$ for $D$. teres f. teres, as $0.35 \%$ for D. graminea, as $4.37 \%$ for R. commune, as $0.53 \%$ for $E$. graminis f. sp. hordei, as $0.06 \%$ for $P$. striiformis, as $0.47 \%$ for $P$. hordei, $0.03 \%$ for $P$. graminis f. sp. tritici. The following wheat disease causing agents were found: E. graminis f. sp. tritici, P. striiformis, P. recondita f. sp. tritici, P. graminis f. sp. tritici, Septoria tritici, Pyrenophora triticirepentis and, Alternaria sp. Mean prevalences of these diseases were determined as $0.46 \%$ for $E$. graminis f. sp. tritici, as $1.94 \%$ for $P$. striiformis, as $0.20 \%$ for $P$. recondita f. sp. tritici, as $1.43 \%$ for $P$. graminis f. sp. tritici, as $1.35 \%$ for $S$. tritici, as $0.20 \%$ for $P$. tritici-repentis, as $0.09 \%$ for Alternaria sp.

Keywords: Wheat, barley, fungal leaf diseases, survey, Kırıkkale

\footnotetext{
${ }^{1} \mathrm{Bu}$ çalışma Hacı Yunus Özdemir'in dönem projesinden üretilmiștir.

${ }^{2}$ Gıda Tarım ve Hayvancılık Bakanlığı, Bahşili Tarım İlçe Müdürlüğü, Kırıkkale

${ }^{3}$ Ankara Üniversitesi, Ziraat Fakültesi, Bitki Koruma Bölümü, Dışkapı, Ankara

Sorumlu Yazar (Corresponding author) e-mail: karakaya@agri.ankara.edu.tr

Alınış (Received): 21.10.2016, Kabul ediliş (Accepted): 06.06.2017
} 


\section{ÖZ}

$\mathrm{Bu}$ çalışma ile Kırıkkale ili arpa ve buğday tarlalarında görülen yaprak hastalıkları belirlenmiştir. 2015 yılında Kırıkkale ilinin merkezi ve 8 ilçesinde sürvey çalışmaları yürütülmüş ve hastalıkların yaygınlıkları ve şiddetleri belirlenmiştir. 128 arpa tarlası ve 172 buğday tarlası olmak üzere toplam 300 tarla incelenmiştir. İncelenen arpa tarlalarında Drechslera teres f. maculata, Drechslera teres f. teres, Drechslera graminea, Rhynchosporium commune, Erysiphe graminis f. sp. hordei, Puccinia striiformis, Puccinia hordei ve Puccinia graminis f. sp. tritici tarafından oluşturulan hastalıklara rastlanmıştır. Belirlenen bu hastalıkların yaygınlık oranları ortalama olarak D. teres f. maculata \%5.63, D. teres f. teres \%1.77, D. graminea \%0.35, R. commune \%4.37, E. graminis f. sp. hordei $\% 0.53$, P. striiformis \%0.06, P. hordei \%0.47, P. graminis f. sp. tritici $\% 0.03$ oranlarında bulunmuştur. İncelenen buğday tarlalarında E. graminis f. sp. tritici, $P$. striiformis, $P$. recondita f. sp. tritici, P. graminis f. sp. tritici, Septoria tritici, Pyrenophora tritici-repentis ve Alternaria sp. türleri tarafından oluşturulan hastalıklara rastlanmıştır. Belirlenen bu hastalıkların yaygınlıkları ortalama olarak E. graminis f. sp. tritici \%0.46, P. striiformis $\% 1.94, P$. recondita f. sp. tritici \%0.20, P. graminis f. sp. tritici \%1.43, S. tritici \%1.35, $P$. tritici-repentis \%0.20, Alternaria sp. \%0.09 oranlarında bulunmuştur.

Anahtar kelimeler: Buğday, arpa, fungal yaprak hastalıkları, survey, Kırıkkale

\section{GíRiș}

Tahıllar dünyada ve Türkiye'de en çok ekilip üretilen ürünler arasında bulunmaktadır. Gerek ekiliş alanı ve gerekse üretim miktarı yönünden tahıllar içerisinde buğday (Triticum aestivum, Triticum durum) ve arpa (Hordeum vulgare) ilk sıralarda yer almaktadır (Kün 1996, Geçit ve ark. 2009). Ülkemizde buğday ekim alan1 8.1 milyon hektar, üretim 19.6 milyon ton ve ortalama verim ise 244 $\mathrm{kg} /$ dekardır (Anonim 2010). Arpa bitkisinin ise ülkemizde 2.75 milyon ha alanda 7.1 milyon ton üretimi yapılmakta olup ortalama verim $2653 \mathrm{~kg} / \mathrm{ha}$ ' dır (Anonim 2013).

Bütün kültür bitkilerinde olduğu gibi arpa ve buğdayda da verimi ve kaliteyi etkileyen hastalıklar bulunmaktadır (Mathre 1982, Bockus et al. 2010). Bu çalışma ile Kırıkkale ilinde yetiştirilen arpa ve buğday bitkilerinde görülen fungal yaprak hastalıkları belirlenmiştir. $\mathrm{Bu}$ çalışmanın bir özeti daha önce yayınlanmıştır (Özdemir ve ark. 2016).

\section{MATERYAL VE METOT}

Bu çalışma 19.05.2015-13.06.2015 tarihleri arasında Kırıkkale ilinin arpa ve buğday yetiştiriciliği yapılan Kırıkkale merkezi ve 8 ilçesinde yürütülmüştür. Kırıkkale ilinde, arpa ve buğday yetiştiriciliği yapılan tarlalarda sapa kalkma ve olgunlaşmadan önceki dönemde ve başaklanma döneminde gözlemler yapılmış ve örnekler alınmıştır. Örneklemede sistematik örnekleme yöntemi kullanılmıştır (Aktaş 2001). Tarlalar arası yol boyunca ilerleyerek yaklaşık 1-20 kilometrede durularak tarlalardan örnek alınmıştır. Tarlaların seçiminde bölgeyi temsil edebilme 
özelliği de dikkate alınmıştır. Kırıkkale ilinde 1.217.194 dekar buğday alanından 5624 dekara karşı1ık gelen 172 buğday tarlası incelenmiştir. Bu alan ekili buğday alanlarının \%0.462'ini oluşturmuştur. Kırıkkale ilinde 395.589 dekar arpa alanından 4287 dekara karşılık gelen 128 arpa tarlası incelenmiştir. Bu alan ekili arpa alanlarının \%1.083'ünü oluşturmuştur. Buğday ve arpa ekim alanları verileri Kırıkkale Gıda Tarım ve Hayvancılık İl Müdürlügünnden elde edilmiştir.

Bitki örnekleri belirtilerine göre sınıflandırılıp teşhisleri yapılmıştır. Bazı örnekler laboratuvarda stereo mikroskop ve 1şık mikroskobu altında incelenmiştir. Kırıkkale ili arpa ve buğday tarlalarında hastalık belirtilerine göre makroskobik gözlemler yapılmıştır. Tam olarak teşhis edilemeyen hastalık etmenleri laboratuvara getirilmiş ve detaylı olarak incelenmişlerdir. Bu çalışmalar neticesinde yapılan teşhisler kaydedilmiş ve hastalıkların tarladaki yaygınlıkları belirlenmiştir. Her bir tarla "W" şeklinde gezilerek en az 100 bitki incelenmiştir.

Bazı örnekler Patates Dekstroz Agar (PDA) ve V8 agar ortamlarında geliştirilmiştir. Ayrıca bazı örneklerde nemli hücre yöntemi sonucunda gelişen konidi ve konidioforlar stereomikroskop altında incelenmiştir. Bazı funguslarda agar ortamlarında gelişen spor yapıları 1şık mikroskobu ile incelenmiştir. Teşhis çalışmalarında Ellis (1971), Mathre (1982), Bockus et al. (2010) ve Niks et al. (1989) kullanılmıştır. Hastalık şiddetlerinin belirlenmesinde Saari and Prescott (1975) tarafından geliştirilen skala kullanılmıştır (Şekil 1). Ortalama yaygınlığın ve şiddetin hesaplanmasında hastalık görülmeyen tarlalar da dikkate alınmıştır.

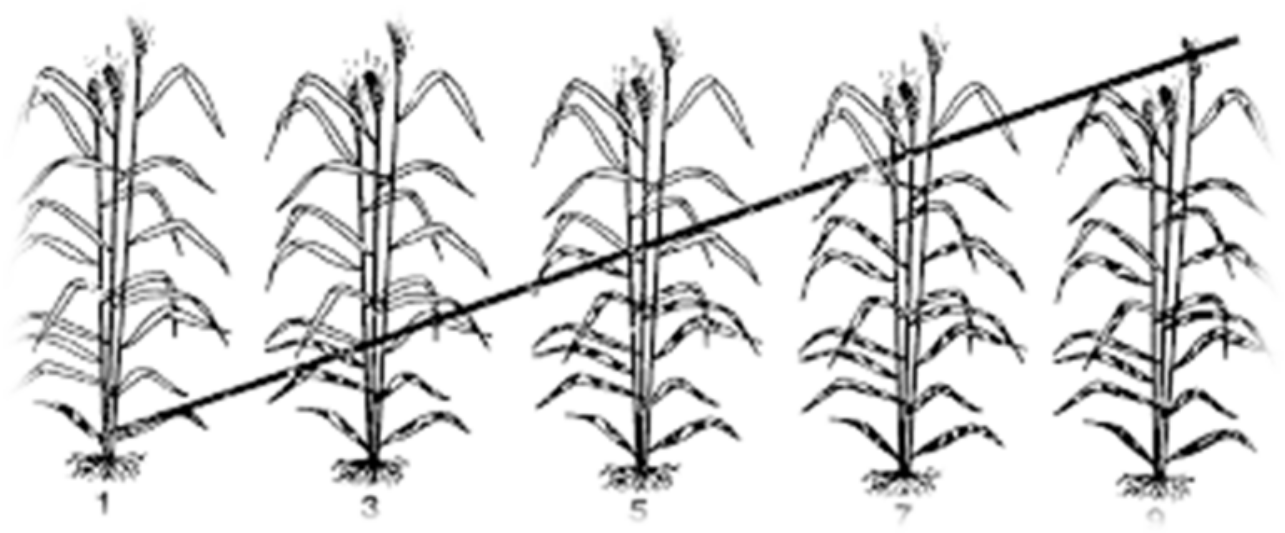

Şekil 1. Kırıkkale ilinde arpa ve buğdayda görülen yaprak hastalıklarının şiddetinin belirlenmesinde kullanılan Saari ve Prescott skalası (Saari and Prescott 1975). 


\section{SONUÇLAR VE TARTIŞMA}

Kırıkkale merkez ve ilçelerinde yapılan sürvey çalışmaları neticesinde Arpada ağbenek hastalığının iki formu, nokta formu Drechslera teres f. maculata ve ağ formu Drechslera teres f. teres, Çizgili yaprak lekesi (Drechslera graminea), Külleme (Erysiphe graminis f. sp. hordei), Sarı pas (Puccinia striiformis), Kara pas (Puccinia graminis f. sp. tritici), Kahverengi pas (Puccinia hordei), Arpa yaprak lekesi (Rhynchosporium commune) hastalıkları makroskobik olarak teşhis edilmiştir. Zaffarano et al. (2011) arpa ve diğer Hordeum türlerini ve Bromus diandrus'u enfekte eden Rhynchosporium izolatlarını Rhynchosporium commune olarak isimlendirmişlerdir. Çavdar ve tritikale bitkilerini enfekte eden izolatlar için Rhynchosporium secalis ismi muhafaza edilmiştir.

Kırıkkale merkez ve ilçelerde yapılan sürvey çalışmalarında Buğdayda külleme Blumeria graminis f. sp. tritici (eş anlamlısı: Erysiphe graminis f. sp. tritici), Sarı pas (P. striiformis), Kahverengi pas (Puccinia recondita f. sp. tritici), Kara pas ( $P$. graminis f. sp. tritici) ve Septorya yaprak lekesi (Septoria tritici) hastalıkları makroskobik olarak teşhis edilmiştir.

Pyrenophora tritici-repentis ve Alternaria sp. nemli hücre ve agar yöntemleri kullanılarak teşhis edilmiştir.

Kara pas (P. graminis f. sp. tritici) etmeninin sapta bulunan püstülleri makroskobik olarak incelenmiştir. Etmen ayrıca ürediniosporlarının ve teliosporlarının özellikleri bakımından mikroskop altında incelenmiştir. Kahverengi pas (Puccinia hordei ve P. recondita f. sp. tritici) ayrımı ise tarlada makroskobik olarak yapıldığı gibi spor morfolojileri de incelenmiştir. Pas etmenleri spor morfolojilerine ve belirtilerine göre teşhis edilmiş̧ir. $P$. hordei için hem tek hem de iki hücreli mezosporların varlığı ve $P$. recondita $\mathrm{f}$. sp. tritici için ise yalnızca iki hüreli mezosporların varlığına bakılmıştır (Mathre 1982, Niks et al. 1989).

Kırıkkale ilinde incelenen 128 arpa tarlasının 101'inde D. teres f. maculata, 59'unda $D$. teres f. teres, 14 'ünde $D$. graminea, 117'sinde $R$. commune, 34'ünde E. graminis f. sp. hordei, 6'sinda $P$. striiformis, 28'inde $P$. hordei, 3'ünde $P$. graminis f. sp. tritici tarafından oluşturulan hastalıklara rastlanmıştır. Sürvey yapılan Kırıkkale merkezi ve Keskin, Balışeyh, Yahşihan, Bahşili, Karakeçili, Delice, Sulakyurt ve Çelebi ilçelerinde arpa bitkisinde $D$. teres $\mathrm{f}$. maculata, $D$. teres f. teres, $R$. commune, $E$. graminis f. sp. hordei; Kırıkkale Merkez ve Keskin, Balışeyh, Yahşihan, Bahşili, Karakeçili, Delice ve Sulakyurt ilçelerinde P. hordei; Kırıkkale Merkez ve Bahşili, Karakeçili, Delice ilçelerinde P. striiformis; Keskin, Bahşili, Karakeçili, Sulakyurt ve Çelebi ilçelerinde D. graminea; Yahşihan ve Karakeçili ilçelerinde P. graminis f. sp. tritici türleri tarafından oluşturulan hastalık etmenlerine rastlanmıştır. Birçok tarlada birden fazla hastalık etmeni görülmüştür (Çizelge 1 ve 2) (Şekil 2 ve 3). 


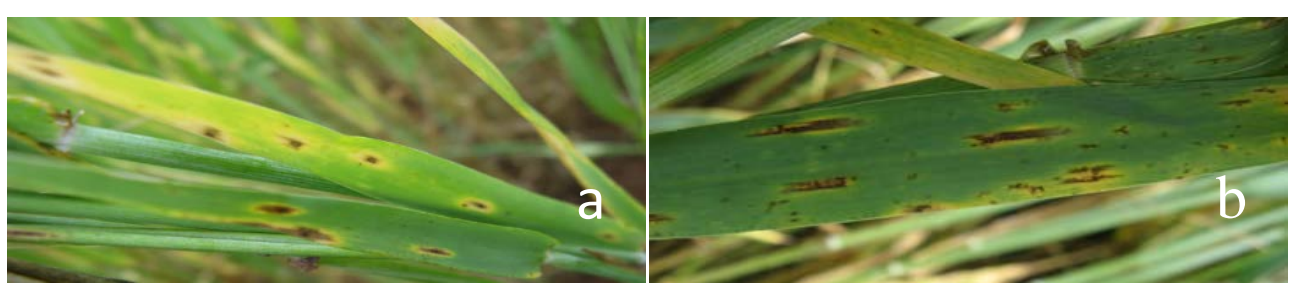

Şekil 2. Kırıkkale ilinde arpalarda görülen yaprak hastalıkları a) Ağ benek hastalığının nokta formu, b) A ̆g benek hastalı̆̆ının ağ formu

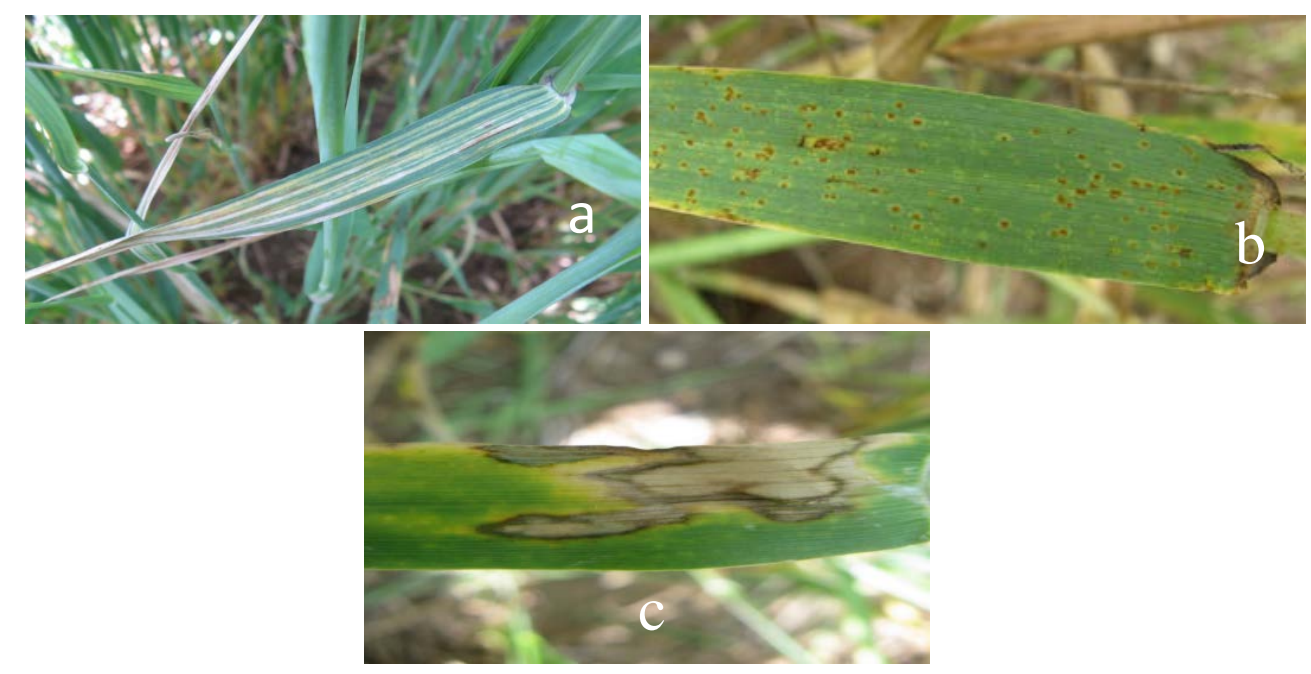

Şekil 3. Kırıkkale ilinde arpalarda görülen yaprak hastalıkları a) Çizgili yaprak lekesi hastalığı, b) Kahverengi pas hastalığı, c) Rhynchosporium yaprak lekesi hastalığı

Kırıkkale ili merkez ve ilçelerinde buğday ekim alanlarında yaprak hastalıklarına neden olan fungal etmenleri tespit etmek amacıyla Merkez, Keskin, Balışeyh, Yahşihan, Bahşili, Karakeçili, Delice, Sulakyurt ve Çelebi ilçelerinde toplam 172 tarla incelenmiştir. İncelenen 172 tarlanın 36'sında E. graminis f. sp. tritici, 87'sinde $P$. striiformis, 20'sinde $P$. recondita f. sp. tritici, 79' unda $P$. graminis f. sp. tritici, 70'inde S. tritici, 12'sinde P. tritici-repentis ve 8'inde Alternaria sp. tarafindan oluşturulan hastalıklara rastlanmıştır. Sürvey yapılan Kırıkkale Merkez, Keskin, Balışeyh, Yahşihan, Bahşili, Karakeçili, Delice, Sulakyurt, Çelebi ilçelerinde buğday bitkilerinde E. graminis f. sp. tritici, P. striiformis, P. graminis f. sp. tritici, S. tritici; Kırıkkale Merkez, Yahşihan, Karakeçili, Sulakyurt ve Çelebi ilçelerinde $P$. tritici-repentis; Balışeyh, Bahşili, Karakeçili, Delice ve Sulakyurt ilçelerinde $P$. recondita f. sp. tritici; Keskin, Balışeyh, Yahşihan, Bahşili ve Delice ilçelerinde Alternaria sp. tarafindan oluşturulan hastalıklara rastlanmıştır. Birçok tarlada birden fazla hastalık etmeni görülmüştür (Çizelge 3 ve 4) (Şekil 4 ve 5). 


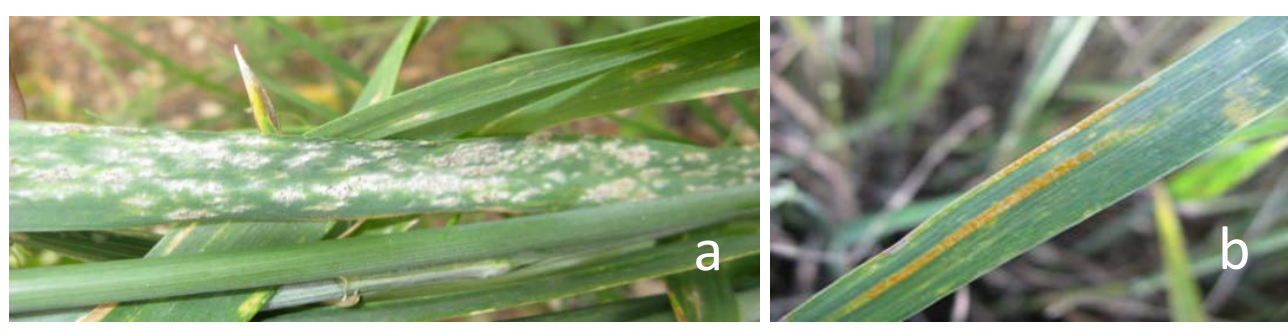

Şekil 4. Kırıkkale ilinde buğdaylarda görülen yaprak hastalıkları a) Külleme hastalığı, b) Sarı pas hastalı̆̆
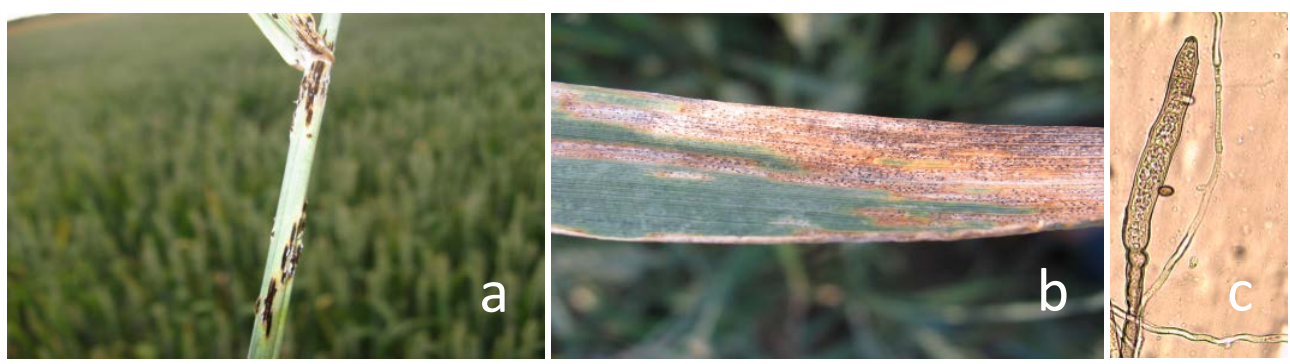

Şekil 5. Kırıkkale ilinde buğdaylarda görülen yaprak hastalıkları a) Kara pas hastalığı, b) Septorya yaprak lekesi hastalığ 1 c) Pyrenophora tritici-repentis hastalık etmeninin konidisi 

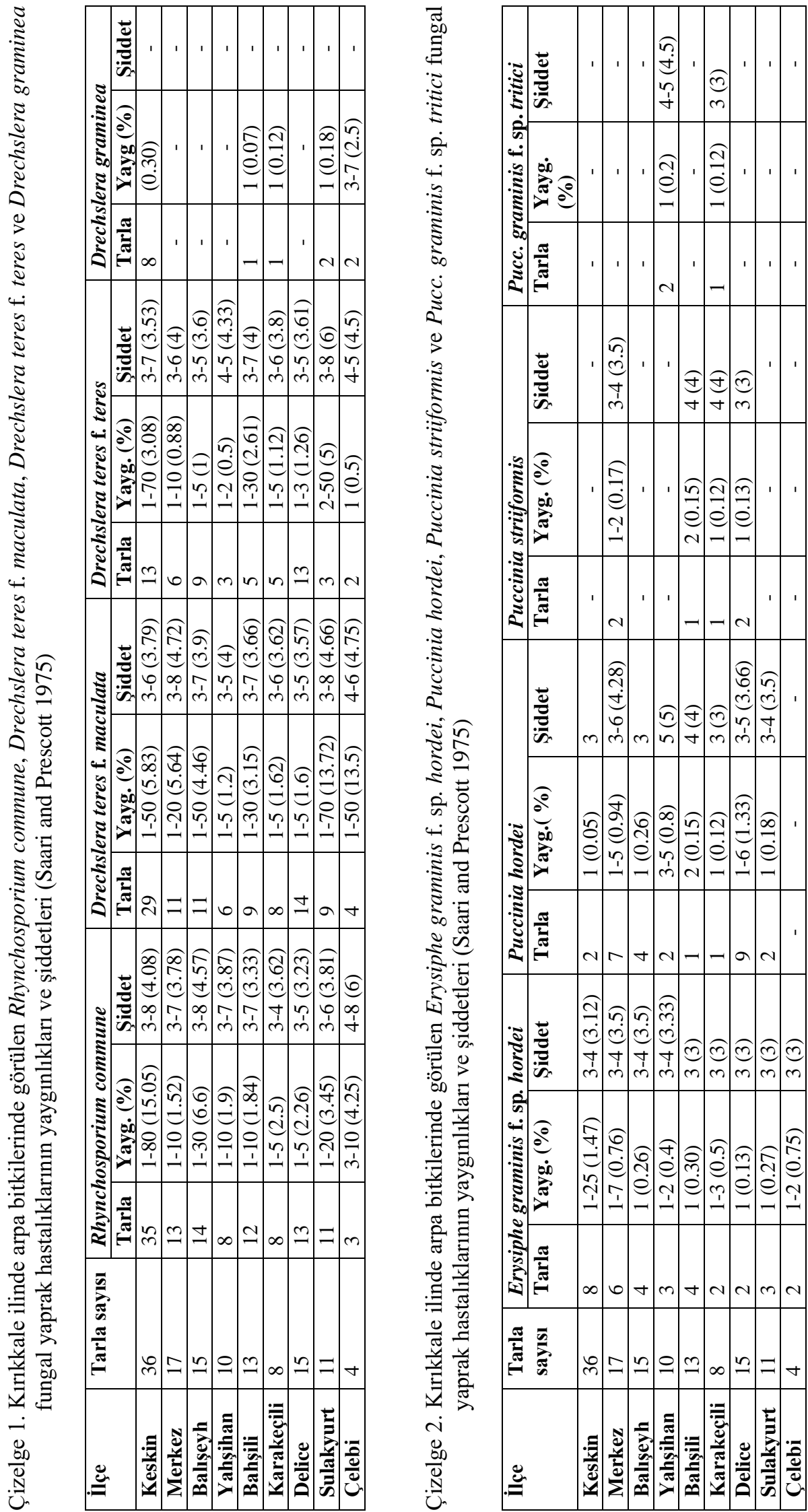

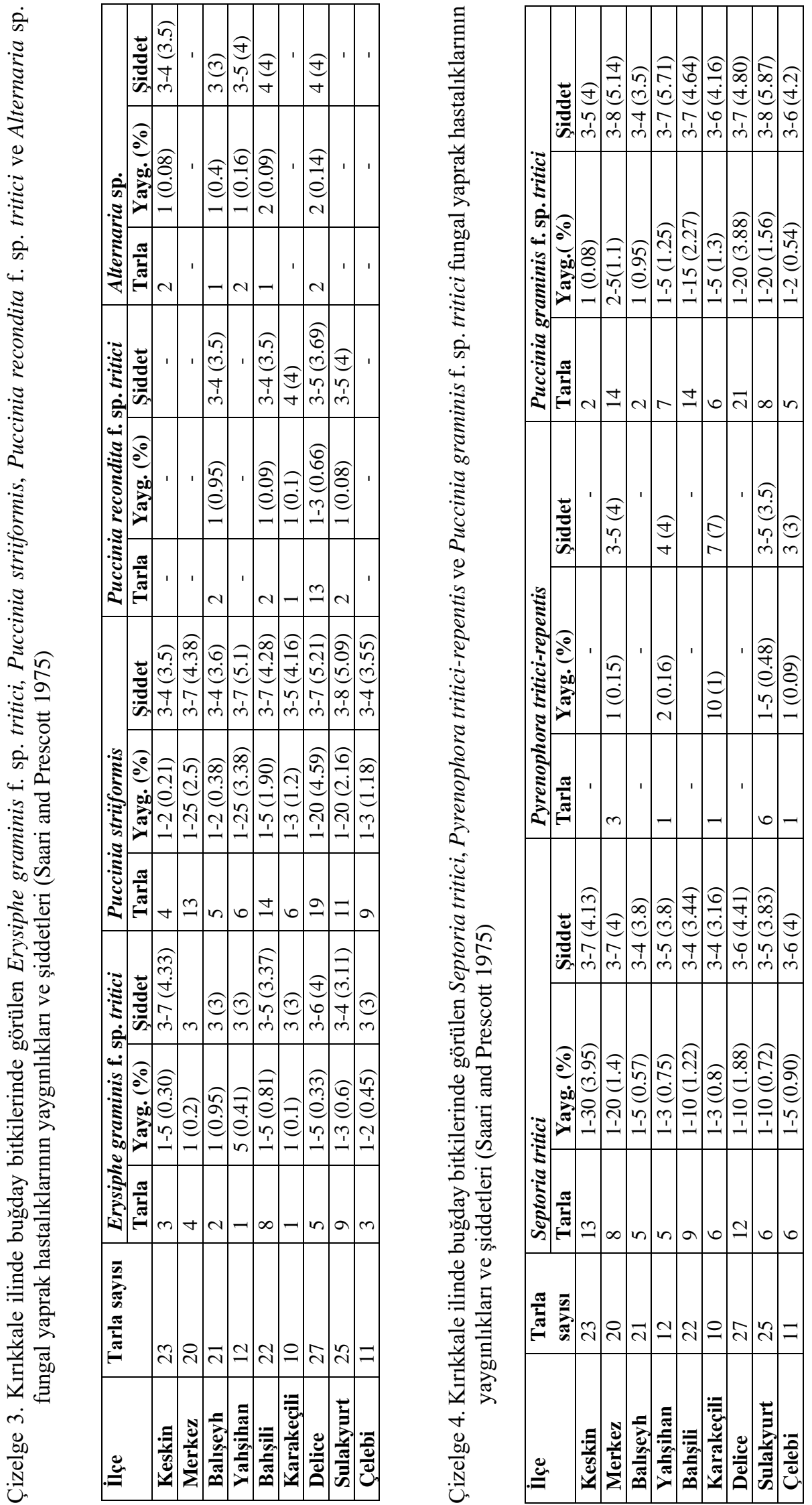
Kırıkkale ilinde buğday ve arpa ekim alanlarında tespit edilen fungal yaprak hastalıkları ile ilgili veriler Çizelge 1, 2, 3 ve 4 'te verilmiştir. Çizelgeler incelendiğinde aşağıda belirtilen sonuçlar elde edilmiştir.

Keskin ilçesinde $R$. commune hastalık etmeni incelenen 36 arpa tarlasının 35'inde görülmüştür. Keskin ilçesinde $R$. commune'nin yaygınlığı \%1 ile \%80 (incelenen tarlalarda bitkilerin \%1'i ile \%80'i arasında hastalık görülmüştür) arasında değişmiştir. Ortalama yaygınlık \%15.05 (100 bitkiden 15.05 ' inde hastalık görülmüş) olarak bulunmuştur. $R$. commune'nin hastalık şiddeti ise 3 ile 8 arasında değişmiştir. Hastalık şiddeti ortalama 4.08 olarak bulunmuştur. İlçede D. teres etmeninin iki formu da bulunmuştur. D. teres f. maculata'nın yaygınlığ $\% 1$ ile \%50 arasında değişmiştir. Ortalama yaygınlık \%5.83 olarak bulunmuştur. D. teres f. maculata'nın hastalık şiddeti ise 3 ile 6 arasında değişmiştir. Hastalık şiddeti ortalama 3.79 olarak bulunmuştur. Bu hastalık etmeni incelenen tarlaların 29'unda görülmüştür. $D$. teres f. teres hastalık etmeni 13 tarlada görülmüştür. $D$. teres f. teres’in yaygınlığı $\% 1$ ile $\% 70$ arasında değişmiş, ortalama yaygınlık \%3.08 arasında bulunmuştur. $D$. teres f. teres'in hastalık şiddeti 3 ile 7 arasında değişmiştir. Hastalık şiddeti ortalama 3.53 olarak bulunmuştur. Keskin ilçesinde D. graminea hastalık etmeni 8 tarlada görülmüştür. Hastalığın yaygınlığ 1 ortalama $\% 0.30$ olarak bulunmuştur. E. graminis f. sp. hordei hastalık etmeni 8 tarlada görülmüştür. Külleme hastalığının yaygınlığı \%1 ile \%25 arasında değişmiştir. Ortalama yaygınlık \%1.47 olarak bulunmuştur. Külleme hastalık şiddeti 3 ile 4 arasında değişmiştir. Hastalık şiddeti ortalama 3.12 olarak bulunmuştur. $P$. hordei hastalık etmeni ise 2 tarlada görülmüştür. $P$. hordei' in yaygınlığ $1 \% 1$ oranında belirlenmiştir. Hastalığın ortalama yaygınlığı ise $\% 0.05$ olarak bulunmuştur. Bu ilçede $P$. hordei'nin şiddeti 3 olarak belirlenmiştir.

Keskin ilçesinde yapılan sürvey çalışmalarında ilçenin buğday ekim alanını temsil edecek sayıda toplam 23 tarla gezilmiştir. Keskin ilçesinde E. graminis f. sp. tritici hastalık etmeni 3 tarlada görülmüştür. Keskin ilçesinde küllemenin yaygınlığ $1 \% 1$ ile $\% 5$ arasında değişmiştir. Ortalama yaygınlık \%0.30 olarak bulunmuştur. E. graminis f. sp. tritici'nin hastalık şiddeti 3 ile 7 arasında değişmiştir. Hastalık şiddeti ortalama olarak 4.33 olarak bulunmuştur. Keskin ilçesinde $P$. striiformis hastalık etmeni 4 tarlada görülmüştür. Sarı pas hastalığının yaygınlığı $\% 1$ ile $\% 2$ arasında değişmiştir. Ortalama yaygınlık \%0.21 olarak bulunmuştur. P. striiformis' in hastalık şiddeti 3 ile 4 arasında değişmiştir. Hastalık şiddeti ortalama 3.5 olarak bulunmuştur. Keskin ilçesinde $P$. graminis f. sp. tritici hastalık etmeni 2 tarlada görülmüştür. Kara pasın yaygınlığ $\% 1$ olarak bulunmuştur. Ortalama yaygınlık \%0.08 olarak tespit edilmiştir. P. graminis f. sp. tritici'nin hastalık şiddeti 5 ile 3 arasında değişmiştir. Hastalık şiddeti ortalama 4 olarak bulunmuştur. S. tritici hastalık etmeni 13 tarlada görülmüştür. Septoria yaprak lekesi hastalığının yaygınlığı \%1 ile \%30 arasında değişmiştir. Ortalama yaygınlık \%3.95 olarak bulunmuştur. S. tritici'nin hastalık şiddeti 3 ile 7 arasında değişmiştir. Hastalık şiddeti ortalama 4.13 olarak bulunmuştur. Alternaria sp. hastalık etmeni ise 2 tarlada görülmüştür. Alternaria sp.' nin yaygınlığı \%1 olarak belirlenmiştir. Ortalama yaygınlık \%0.08 olarak 
bulunmuştur. Alternaria sp.'nin hastalık şiddeti 3 ile 4 arasında değişmiştir. Hastalık şiddeti ortalama 3.5 olarak bulunmuştur. Keskin ilçesindeki sürvey yapılan 7 adet buğday tarlasında herhangi bir hastalık görülmemiştir.

Kırıkkale Merkez ilçede yapılan sürvey çalışmalarında, arpa ekim alanını temsil edebilecek sayıda toplam 17 tarla gezilmiştir. Kırıkkale Merkez ilçede D. teres'in iki formu da görülmüştür. D. teres f. maculata hastalık etmeni 11 tarlada belirlenmiştir. D. teres f. maculata'nın yaygınlığ $1 \% 1$ ile $\% 20$ arasında değişmiştir. Kırıkkale merkezde hastalığın ortalama yaygınlığ $\% 5.64$, şiddeti ise 3 ile 8 arasında değişmiştir. D. teres f. maculata'nın hastalık şiddeti ortalama 4.72 olarak bulunmuştur. $D$. teres f. teres hastalık etmeni 6 tarlada görülmüştür. Kırıkkale Merkezde hastalık etmeninin yaygınlı̆̆ $1 \% 1$ ile \%10 arasında değişmiştir. Ortalama yaygınlığı \%0.88 olarak bulunmuş, hastalık şiddeti ise 3 ile 6 arasında değişmiştir. $D$. teres f. teres'in ortalama şiddeti 4 olarak bulunmuştur. Kırıkkale Merkezde $R$. commune hastalık etmeni 13 tarlada görülmüştür. Arpa yaprak lekesi hastalığının yaygınlığ $\% 1$ ile \%10 arasında değişmiştir. Hastalık etmeninin ortalama yaygınlığ 1 \%1.52 olarak bulunmuştur. Hastalığın şiddeti ise 3 ile 7 arasında değişmiştir. Ortalama hastalık şiddeti 3.78 olarak bulunmuştur. Kırıkkale Merkezde E. graminis f. sp. hordei 6 tarlada görülmüştür. Külleme hastalığının yaygınlığı \%1 ile \%7 arasında değişmiştir. E. graminis f. sp. hordei'nin ortalama yaygınlığ $1 \% 0.76$ olarak bulunmuştur. Hastalık şiddeti 3 ile 4 arasında değişmiştir. Ortalama hastalık şiddeti ise 3.5 olarak bulunmuştur. Kırıkkale Merkezde $P$. striiformis 2 tarlada görülmüştür. $P$. striiformis hastalık etmeninin yaygınlığ $\% 1$ ile $\% 2$ arasında değişmiştir. $P$. striiformis'in ortalama yaygınlığ $\% 0.17$ olarak bulunmuştur. Sarı pas hastalığının şiddeti 3 ile 4 arasında değişmiştir. Ortalama hastalık şiddeti 3.5 olarak bulunmuştur. Kırıkkale Merkezde $P$. hordei hastalık etmeni 7 tarlada görülmüştür. $P$. hordei hastalık etmeninin yaygınlığı $\% 1$ ile $\% 5$ arasında değişmiştir. Ortalama yaygınlığ 1 $\% 0.94$ olarak bulunmuştur. $P$. hordei hastalık şiddeti 3 ile 6 arasında değişmiş, ortalama hastalık şiddeti ise 4.28 olarak bulunmuştur.

Kırıkkale Merkez ilçede yapılan sürvey çalışmalarında buğday ekim alanını temsil edebilecek sayıda toplam 20 tarla gezilmiştir. Kırıkkale Merkez ilçede E. graminis f. sp. tritici hastalık etmeni 4 tarlada görülmüştür. Hastalık etmeninin yaygınlığ $\% 1$ olarak belirlenmiştir. Ortalama yaygınl 1 ğ $1 \% 0.2$ olarak bulunmuştur. Hastalık şiddeti hastalığın görüldüğü bütün tarlalarda 3 olarak belirlenmiştir. Kırıkkale Merkezde $P$. striiformis hastalık etmeni 13 tarlada görülmüştür. Sarı pas hastalığının yaygınlığ 1 $\% 1$ ile \%25 arasında değişmiştir. P. striiformis'in ortalama yaygınlığı \%2.5 olarak bulunmuştur. Hastalık şiddeti 3 ile 7 arasında değişmiş, ortalama hastalık şiddeti ise 4.38 olarak bulunmuştur. $P$. graminis $\mathrm{f}$. sp. tritici hastalık etmeni ise 14 tarlada görülmüştür. Hastalık etmeninin yaygınlığı $\% 2$ ile $\% 5$ arasında değişmiştir. $P$. graminis f. sp. tritici'nin ortalama yaygınlığ $\% 1.1$ olarak bulunmuştur. Hastalık şiddeti 3 ile 8 arasında değişmiş, ortalama hastalık şiddeti 5.14 olarak bulunmuştur. Kırıkkale Merkezde Septorya yaprak lekesi hastalığı 8 tarlada görülmüsstür. S. tritici hastalık etmeninin yaygınlığı \%1 ile \%20 arasında değişmiş̧tir. Ortalama yaygınlığı 
\%1.4 olarak bulunmuş, hastalık şiddeti ise 3 ile 7 arasında değişmiştir. Ortalama hastalık şiddeti 4 olarak bulunmuştur. $P$. tritici-repentis hastalık etmeni 3 tarlada görülmüştür. $P$. tritici-repentis hastalık etmeninin yaygınlığ $\% 1$ olarak belirlenmiş ortalama yaygınlığ ise \%0.15 olarak bulunmuştur. Hastalık şiddeti 3 ile 5 arasında değişmiş, ortalama hastalık şiddeti 4 olarak bulunmuştur.

Kırıkkale ilinin Balışeyh ilçesinde yapılan sürvey çalışmasında, ilçenin arpa ekim alanını temsil edecek sayıda toplam 15 tarla incelenmiştir. Bu ilçede $D$. teres hastalık etmeninin her iki formu da görülmüştür. Balışeyh ilçesinde D. teres f. maculata hastalık etmeni 11 tarlada görülmüştür. Etmenin yaygınlığ $1 \% 1$ ile $\% 50$ arasında değişmiştir. Ağ benek hastalığı nokta formunun ortalama yaygınlığı \%4.46 olarak bulunmuştur. Hastalık şiddeti 3 ile 7 arasında değişmiş, ortalama hastalık şiddeti 3.90 olarak bulunmuştur. $D$. teres f. teres hastalık etmeni 9 tarlada görülmüştür. $D$. teres f. teres hastalık etmeninin yaygınlığ $1 \% 1$ ile $\% 5$ arasında değişmiştir. Ağ benek hastalığ a $\breve{g}$ formunun ortalama yaygınlığ $1 \% 1$ olarak bulunmuştur. Hastalığın ağ formunun şiddeti 3 ile 5 arasında değişmiş, ortalama şiddeti ise 3.6 olarak bulunmuştur. $R$. commune hastalık etmeni 14 tarlada görülmüştür. Hastalık etmeninin yaygınlığ $1 \% 1$ ile \%30 arasında değişmiş, ortalama yaygınlığ ise \%6.6 olarak bulunmuştur. Balışeyh ilçesinde Arpa yaprak lekesi hastalığının şiddeti 3 ile 8 arasında değişmiştir. Ortalama hastalık şiddeti 4.57 olarak bulunmuştur. Külleme hastalığ 14 tarlada görülmüştür. E. graminis f. sp. hordei hastalık etmeninin yaygınlığı \%1 olarak tespit edilmiş, ortalama yaygınlığı ise \%0.26 olarak bulunmuştur. Hastalığın şiddeti 3 ile 4 arasında değişmiş, ortalama hastalık şiddeti ise 3.5 olarak bulunmuştur. $P$. hordei hastalık etmeni 4 tarlada görülmüştür. Hastalık etmeninin yaygınlığ 4 tarlada da \%1 olarak tespit edilmiş, ortalama yaygınlığ ise $\% 0.26$ olarak tespit edilmiştir. Hastalık şiddeti 4 tarlada da 3 olarak bulunmuşstur.

Balışeyh ilçesinde yapılan sürvey çalışmasında, ilçenin buğday ekim alanını temsil edebilecek sayıda toplam 21 tarla gezilmiştir. Bu ilçede Külleme hastalığ 2 tarlada görülmüştür. E. graminis f. sp. tritici hastalık etmeninin yaygınlığ $1 \% 1$ olarak tespit edilmiş, ortalama yaygınlığ 1 ise $\% 0.95$ olarak bulunmuştur. Hastalık etmeninin şiddeti 2 tarlada da 3 olarak belirlenmiştir. Balışeyh ilçesinde $P$. striiformis hastalık etmeni 5 tarlada görülmüştür. Hastalık etmeninin yaygınlığı \%1 ile \%2 arasında değişmiş, ortalama yaygınlığ 1 ise $\% 0.38$ olarak bulunmuştur. Hastalık etmeninin şiddeti 3 ile 4 arasında değişmiş, ortalama hastalık şiddeti 3.6 olarak bulunmuştur. $P$. recondita f. sp. tritici hastalık etmeni 2 tarlada görülmüştür. Hastalık etmeninin yaygınlığ $\% 1$ olarak tespit edilmiş, ortalama yaygınlığ 1 ise \%0.95 olarak bulunmuştur. Hastalık şiddeti 3 ile 4 arasında değişmiş, ortalama hastalık şiddeti 3.5 olarak bulunmuştur. $P$. graminis f. sp. tritici hastalık etmeni 2 tarlada görülmüştür. Hastalık etmeninin yaygınlığı \% olarak tespit edilmiş, ortalama yaygınlığı ise $\% 0.95$ olarak bulunmuştur. Hastalık şiddeti 3 ile 4 arasında değişmiş, ortalama hastalık şiddeti ise 3.5 olarak bulunmuştur. Balışeyh ilçesinde Septorya yaprak lekesi 5 tarlada görülmüştür. S. tritici hastalık etmeninin yaygınlığ $1 \% 1$ ile $\% 5$ arasında değişmiştir. Ortalama yaygınlığ $\% 0.57$ olarak bulunmuştur. Hastalık şiddeti 3 ile 4 arasında değişmiş, ortalama hastalık şiddeti ise 3.8 olarak bulunmuştur. Balışeyh 
ilçesinde Alternaria sp. hastalık etmeni 1 tarlada görülmüştür. Alternaria sp. hastalık etmeninin yaygınlığ $\% 1$ olarak tespit edilmiş, ortalama yaygınlık \%0.04 olarak bulunmuştur. Bu ilçede Alternaria sp. hastalık etmeninin hastalık şiddeti 3 olarak tespit edilmiştir. Balışeyh ilçesinde yapılan sürveyde 4 tarlada herhangi bir hastalık görülmemiştir.

Kırıkkale ilinin Yahşihan ilçesinde yapılan sürvey çalışmasında, ilçenin arpa ekim alanını temsil edebilecek sayıda toplam 10 tarla incelenmiştir. $D$. teres hastalık etmeninin iki formu da görülmüştür. Bu ilçede $D$. teres f. maculata hastalık etmeni 6 tarlada görülmüştür. Hastalık etmeninin yaygınlığg $\% 1$ ile $\% 5$ olarak değişmiş, ortalama yaygınlığı ise \%1.2 olarak bulunmuştur. Hastalık etmeninin şiddeti 3 ile 5 arasında değişmiş, ortalama hastalık şiddeti 4 olarak bulunmuştur. Yahşihan ilçesinde $D$. teres f. teres hastalık etmeni 3 tarlada görülmüştür. Etmenin yaygınlığı $\% 1$ ile \%2 olarak tespit edilmiştir. Ortalama yaygınlığ $\% 0.5$ olarak bulunmuştur. Hastalık etmeninin şiddeti 4 ile 5 arasında değişmiştir. Ortalama hastalık şiddeti 4.33 olarak bulunmuştur. Yahşihan ilçesinde $R$. commune hastalık etmeni 8 tarlada görülmüştür. Hastalık etmeninin yaygınlığı $\% 1$ ile $\% 10$ olarak değişmiş, ortalama yaygınlığ ise \%1.9 olarak bulunmuştur. Hastalık etmeninin şiddeti 3 ile 7 arasında değişmiştir. Ortalama hastalık şiddeti 3.87 olarak bulunmuştur. Külleme hastalığı 3 tarlada görülmüştür. E. graminis f. sp. hordei hastalık etmeninin yaygınlığ $\% 1$ ile $\% 2$ arasında değişmiş, ortalama yaygınlığ 1 ise $\% 0.4$ olarak bulunmuştur. Hastalık etmeninin şiddeti 3 ile 4 arasında değişmiş, ortalama hastalık şiddeti 3.33 olarak bulunmuştur. $P$. hordei hastalık etmeni 2 tarlada görülmüştür. Hastalık etmeninin bu tarlalarda yaygınlığ $1 \% 3$ ile $\% 5$, ortalama yaygınlı $\breve{g}_{1}$ ise $\% 0.8$ olarak bulunmuştur. Hastalık etmeninin şiddeti iki tarlada da 5 olarak tespit edilmiştir. Yahşihan ilçesinde P. graminis f. sp. tritici hastalık etmeni 2 tarlada görülmüştür. Bu hastalık etmeninin yaygınlığı iki tarlada da \%1 olarak tespit edilmiştir. P. graminis f. sp. tritici' nin ortalama yaygınlığ $\% 0.2$ olarak bulunmuştur. Hastalık etmeninin şiddeti bu tarlalarda 4 ile 5 olarak tespit edilmiş, ortalama hastalık şiddeti ise 4.5 olarak bulunmuştur.

Kırıkkale ilinin Yahşihan ilçesinde sürvey çalışmasında ilçenin buğday ekim alanını temsil edebilecek sayıda toplam 12 tarla incelenmiştir. Külleme 1 tarlada görülmüştür. E. graminis f. sp. tritici hastalık etmeninin yaygınlığ $\% 5$ olarak tespit edilmiş, ortalama yaygınlı̆ $\mathrm{g} 1$ ise $\% 0.41$ olarak bulunmuştur. Hastalık etmeninin şiddeti bu tarlada 3 olarak tespit edilmiştir. P. striiformis hastalık etmeni 6 tarlada görülmüştür. Hastalık etmeninin yaygınlığ $\% 1$ ile \%25 arasında değişmiş, ortalama yaygınlığ ise \%3.38 olarak bulunmuştur. Hastalık etmeninin şiddeti 3 ile 7 arasında değişmiş, ortalama hastalık şiddeti ise 5.1 olarak bulunmuştur. Yahşihan ilçesinde P. graminis f. sp. tritici hastalık etmeni 7 tarlada görülmüştür. Hastalık etmeninin yaygınlığ $1 \% 1$ ile $\% 5$ arasında değişmiş ortalama yaygınlığ bulunmuştur. Hastalık etmeninin şiddeti 3 ile 7 arasında değişmiş, ortalama hastalık şiddeti 5.71 bulunmuştur. Septorya yaprak lekesi 5 tarlada görülmüştür. S. tritici hastalık etmeninin yaygınlığ $\% 1$ ile \%3 arasında değişmiş, ortalama yaygınlığ 1 ise 
$\% 0.75$ olarak bulunmuştur. Etmenin şiddeti 3 ile 5 arasında değişmiş, ortalama hastalık şiddeti ise 3.8 olarak bulunmuştur. Yahşihan ilçesinde Alternaria sp. hastalık etmeni 2 tarlada görülmüştür. Hastalık etmeninin yaygınlığ i iki tarlada da $\% 1$ olarak tespit edilmiş, ortalama yaygınlığı ise \%0.16 olarak bulunmuştur. Etmenin şiddeti 3 ile 5 arasında değişmiş, ortalama hastalık şiddeti 4 olarak bulunmuştur. P. tritici-repentis hastalık etmeni ise 1 tarlada görülmüştür. Hastalık etmeninin yaygınlığ $1 \% 2$ olarak tespit edilmiş, ortalama yaygınlığ $1 \% 0.16$ olarak bulunmuştur. Etmenin şiddeti bu tarlada 4 olarak bulunmuştur.

Kırıkkale ilinin Bahşili ilçesinde yapılan sürvey çalışmasında ilçenin arpa ekim alanını temsil edebilecek sayıda toplam 13 tarla gezilmiştir. Bu ilçede $D$. teres f. maculata hastalık etmeni 9 tarlada görülmüsstür. Etmenin yaygınlığ $\% 1$ ile \%30 arasında değişmiş, ortalama yaygınlığ ise \%3.15 olarak bulunmuştur. A $\breve{g}$ benek hastalığının nokta formunun hastalık şiddeti 3 ile 7 arasında değişmiş, ortalama hastalık şiddeti ise 3.66 olarak bulunmuştur. Bahşili ilçesinde D. teres f. teres hastalık etmeni 5 tarlada görülmüsstür. $D$. teres f. teres hastalık etmeninin yaygınlığ 1 $\% 1$ ile \%30 arasında değişmiş, ortalama yaygınlığı \%2.61 olarak bulunmuştur. A $\breve{g}$ benek hastalığının ăg formunun hastalık şiddeti 3 ile 7 arasında değişmiştir. Ortalama hastalık şiddeti 4 olarak bulunmuştur. Bahşili ilçesinde D. graminea hastalık etmeni 1 tarlada görünmüştür. Yaygınlığ $1 \% 1$ olarak tespit edilmiş, ortalama yaygınlığı ise $\% 0.07$ olarak bulunmuştur. $R$. commune hastalık etmeni 12 tarlada görünmüş̧ür. Hastalık etmeninin yaygınlığ $\% 1$ ile $\% 10$ arasında değişmiş, ortalama yaygınlığ $1 \% 1.84$ olarak bulunmuştur. $R$. commune hastalık etmeninin şiddeti 3 ile 7 arasında değişmiştir. Ortalama hastalık şiddeti 3.33 olarak bulunmuştur. Külleme hastalığ 4 tarlada görülmüştür. E. graminis f. sp. hordei hastalık etmeninin yaygınlığı 4 tarlada da \%1 olarak tespit edilmiştir. Ortalama yaygınlığı \%0.30 olarak bulunmuştur. E. graminis f. sp. hordei hastalık etmeninin şiddeti 4 tarlada da 3 olarak tespit edilmiştir. Bahşili ilçesinde $P$. striiformis hastalık etmeni 1 tarlada görülmüştür. Hastalık etmeninin yaygınlığ $\% 2$ olarak belirlenmiş, ortalama yaygınlı̆̆ ise \%0.15 olarak bulunmuştur. Etmenin şiddeti 4 olarak tespit edilmiştir. $P$. hordei hastalık etmeni ise 1 tarlada görülmüştür. Etmenin yaygınlığ $\% 2$ olarak belirlenmiş, ortalama yaygınlığ $\% 0.15$ olarak bulunmuştur. Hastalık etmeninin şiddeti 4 olarak belirlenmiştir.

Kırıkkale ilinin Bahşili ilçesinde yapılan sürvey çalışmasında ilçenin buğday ekim alanını temsil edebilecek sayıda toplam 22 tarla gezilmiştir. Külleme hastalığı 8 tarlada görülmüştür. Hastalık etmeninin yaygınlığ $1 \% 1$ ile $\% 5$ arasında değişmiş, ortalama yaygınlığı ise \%0.81 olarak bulunmuştur. Etmenin şiddeti 3 ile 5 arasında değişmiştir. Ortalama hastalık şiddeti 3.37 olarak bulunmuştur. P. striiformis hastalık etmeni 14 tarlada görülmüştür. Hastalık etmeninin yaygınlığı \%1 ile \%5 arasında değişmiş, ortalama yaygınlığ $1 \% 1.90$ olarak bulunmuştur. P. striiformis hastalık etmeninin şiddeti 3 ile 7 arasında değişmiş, ortalama hastalık şiddeti 4.28 olarak bulunmuştur. Bahşili ilçesinde P. recondita f. sp. tritici hastalık etmeni 2 tarlada görülmüsstür. P. recondita f. sp. tritici hastalık etmeninin yaygınlığ iki tarlada da $\% 1$ olarak tespit edilmiş, ortalama yaygınlığ $1 \% 0.09$ olarak bulunmuştur. Hastalık 
etmeninin şiddeti 3 ile 4 arasında değişmiş, ortalama hastalık şiddeti 3.5 olarak bulunmuştur. $P$. graminis f. sp. tritici hastalık etmeni 14 tarlada görülmüştür. $P$. graminis f. sp. tritici hastalık etmeninin yaygınlığı \%1 ile \%15 arasında değişmiş, ortalama yaygınlığı ise \%2.27 olarak bulunmuştur. Hastalığın şiddeti 3 ile 7 arasında değişmiş, ortalama hastalık şiddeti 4.64 olarak bulunmuştur. Septorya yaprak lekesi 9 tarlada görülmüsşür. S. tritici hastalık etmeninin yaygınlığ $1 \% 1$ ile $\% 10$ arasında değişmiş, ortalama yaygınlığ $\% 1.22$ olarak bulunmuştur. S. tritici'nin hastalık şiddeti 3 ile 4 arasında değişmiş, ortalama hastalık şiddeti 3.44 olarak bulunmuştur. Bahşili ilçesinde Alternaria sp. hastalık etmeni 1 tarlada görülmüştür. Alternaria sp. hastalık etmeninin yaygınlığı $\% 2$ olarak tespit edilmiş ortalama yaygınlığ $\% 0.09$ olarak bulunmuştur. Alternaria sp.'nin hastalık şiddeti 4 olarak tespit edilmiştir.

Kırıkkale ilinin Karakeçili ilçesinde yapılan sürvey çalışmasında ilçenin arpa ekim alanını temsil edebilecek sayıda toplam 8 tarla gezilmiştir. Bu ilçede $D$. teres f. maculata hastalık etmeni 8 tarlanın 8 'inde de görülmüştür. $D$. teres f. maculata hastalık etmeninin yaygınlığ $\% 1$ ile $\% 5$ arasında değişmiş, ortalama yaygınlığ ise \%1.62 olarak bulunmuştur. D. teres f. maculata' nın hastalık şiddeti 3 ile 6 arasında değişmiştir. Ortalama hastalık şiddeti 3.62 olarak bulunmuştur. Karakeçili ilçesinde $D$. teres f. teres hastalık etmeni 5 tarlada görülmüsstür. Hastalık etmeninin yaygınlığ 1 $\% 1$ ile $\% 5$ arasında değişmiş, ortalama yaygınlığ $\% 1.12$ olarak bulunmuştur. Hastalık şiddeti 3 ile 6 arasında değişmiş, ortalama hastalık şiddeti 3.8 olarak bulunmuştur. D. graminea hastalık etmeni 1 tarlada görülmüştür. Bu hastalık etmeninin yaygınlığ $\% 1$ olarak bulunmuş, ortalama yaygınlığ 1 ise $\% 0.12$ olarak tespit edilmiştir. $R$. commune hastalık etmeni 8 tarlanın 8 'inde de görülmüştür. Hastalık etmeninin yaygınlığ $\% 1$ ile $\% 5$ arasında değişmiş, ortalama yaygınlığ $\% 2.5$ olarak bulunmuştur. Bu hastalığın şiddeti 3 ile 4 arasında değişmiştir. Ortalama hastalık şiddeti 3.62 olarak bulunmuştur. Karakeçili ilçesinde Külleme hastalığı 2 tarlada görülmüsstür. E. graminis f. sp. hordei hastalık etmeninin yaygınlığı \%1 ile $\% 3$ olarak belirlenmiş, ortalama yaygınlığ $\% 0.5$ olarak bulunmuştur. Hastalığın şiddeti 2 tarlada da 3 olarak belirlenmiştir. $P$. striiformis hastalık etmeni 1 tarlada görülmüştür. $P$. striiformis hastalık etmeninin yaygınlığ $\% 1$ olarak tespit edilmiş, ortalama yaygınlığ $\% 0.12$ olarak bulunmuştur. Hastalığın şiddeti bu tarlada 4 olarak belirlenmiştir. Karakeçili ilçesinde $P$. hordei hastalık etmeni 1 tarlada görülmüştür. Hastalık etmeninin yaygınlığ $1 \% 1$ olarak belirlenmiş, ortalama yaygınlığ ise $\% 0.12$ olarak bulunmuştur. Hastalığın şiddeti bu tarlada 3 olarak belirlenmiştir. P. graminis f. sp. tritici hastalık etmeni 1 tarlada görülmüştür. $P$. graminis f. sp. tritici hastalık etmeninin yaygınl 1 ğ $1 \% 1$ olarak belirlenmiştir. Ortalama yaygınlığ ise $\% 0.12$ olarak bulunmuştur. Hastalık şiddeti 3 olarak belirlenmiştir.

Kırıkkale ilinin Karakeçili ilçesinde yapılan sürvey çalışmasında ilçenin buğday ekim alanını temsil edebilecek sayıda toplam 10 tarla gezilmiştir. Karakeçili ilçesinde Külleme hastalığı 1 tarlada görülmüsşür. Hastalık etmeninin yaygınlığı \%1 olarak belirlenmiş, ortalama yaygınlığ $1 \% 0.1$ olarak bulunmuştur. Hastalık şiddeti 3 olarak belirlenmiştir. Karakeçili ilçesinde P. striiformis hastalık etmeni 6 tarlada 
görülmüştür. Hastalık etmeninin yaygınlığ $\% 1$ ile \%3 arasında değişmiş, ortalama yaygınlığ 1 ise $\% 1.2$ olarak bulunmuştur. P. striiformis'in hastalık şiddeti 3 ile 5 arasında değişmiştir. Ortalama hastalık şiddeti 4.16 olarak bulunmuştur. P. recondita f. sp. tritici hastalık etmeni 1 tarlada görülmüştür. $P$. recondita f. sp. tritici hastalık etmeninin yaygınlığ $1 \% 1$ olarak tespit edilmiş, ortalama yaygınlığ $\% 0.1$ olarak bulunmuştur. Bu hastalığın şiddeti 4 olarak tespit edilmiştir. P. graminis f. sp. tritici hastalık etmeni 6 tarlada görülmüştür. $P$. graminis f. sp. tritici hastalık etmeninin yaygınlığı \%1 ile \%5 arasında değişmiş, ortalama yaygınlığı \%1.3 olarak bulunmuştur. Hastalık şiddeti 3 ile 6 arasında değişmiştir. Ortalama hastalık şiddeti 4.16 olarak bulunmuştur. Karakeçili ilçesinde Septorya yaprak lekesi 6 tarlada görülmüştür. S. tiritici hastalık etmeninin yaygınlığı \%1 ile \%3 arasında değişmiş, ortalama yaygınlığ $1 \% 0.8$ olarak bulunmuştur. Hastalığın şiddeti 3 ile 4 arasında değişmiş, ortalama hastalık şiddeti 3.16 olarak bulunmuştur. P. tritici-repentis hastalık etmeni 1 tarlada görülmüştür. Yaygınlığ $\% 10$ olarak tespit edilmiş, ortalama yaygınlığ $1 \% 1$ olarak bulunmuştur. $P$. tritici-repentis' in hastalık şiddeti 7 olarak tespit edilmiştir.

Kırıkkale ilinin Delice ilçesinde yapılan sürvey çalışmasında ilçenin arpa ekim alanını temsil edebilecek sayıda toplam 15 tarla gezilmiştir. Delice ilçesinde $D$. teres f. maculata hastalık etmeni 14 tarlada görülmüştür. Hastalık etmeninin yaygınlığı $\% 1$ ile $\% 5$ arasında değişmiş, ortalama yaygınlığı \%1.6 olarak bulunmuştur. Hastalığın şiddeti 3 ile 5 arasında değişmiş, ortalama hastalık şiddeti ise 3.57 olarak bulunmuştur. $D$. teres f. teres hastalık etmeni 13 tarlada görülmüştür. Hastalık etmeninin yaygınlığı \%1 ile \%3 arasında değişmiş, ortalama yaygınlığ 1 ise $\% 1.26$ olarak bulunmuştur. $D$ teres f. teres'in hastalık şiddeti 3 ile 5 arasında değişmiştir. Ortalama hastalık şiddeti 3.61 olarak bulunmuştur. $R$. commune hastalık etmeni 13 tarlada görülmüsstür. $R$. commune hastalık etmeninin yaygınlığı $\% 1$ ile $\% 5$ arasında değişmiş, ortalama yaygınlığ $1 \% 2.26$ olarak bulunmuştur. Hastalık şiddeti 3 ile 5 arasında değişmiş, ortalama hastalık şiddeti 3.23 olarak bulunmuştur. Külleme hastalığ 2 tarlada görülmüştür. E. graminis f. sp. hordei hastalık etmeninin yaygınlığ 2 tarlada da \%1 olarak bulunmuş, ortalama yaygınlığ 1 ise \%0.13 olarak tespit edilmiştir. E. graminis f. sp. hordei'nin hastalık şiddeti 2 tarlada da 3 olarak belirlenmiştir. Delice ilçesinde $P$. striiformis hastalık etmeni 2 tarlada görülmüştür. $P$. striiformis hastalık etmeninin yaygınlığı iki tarlada da \%1 olarak bulunmuş, ortalama yaygınlığ ise $\% 0.13$ olarak belirlenmiştir. Sarı pasın hastalık şiddeti iki tarlada da 3 olarak tespit edilmiştir. Delice ilçesinde $P$. hordei hastalık etmeni 9 tarlada görülmüştür. $P$. hordei hastalık etmeninin yaygınlığ $\% 1$ ile $\% 6$ arasında değişmiş, ortalama yaygınlığ ise \%1.33 olarak bulunmuştur. Hastalığın şiddeti 3 ile 5 arasında değişmiş̧tir. Ortalama hastalık şiddeti 3.66 olarak bulunmuştur.

Kırıkkale ilinin Delice ilçesinde yapılan sürvey çalışmasında, ilçenin buğday ekim alanını temsil edebilecek sayıda toplam 27 tarla gezilmiştir. Delice ilçesinde Külleme hastalığ 5 tarlada görülmüştür. E. graminis f. sp. tritici hastalı etmeninin yaygınlığ $1 \% 1$ ile $\% 5$ arasında değişmiş, ortalama yaygınlığ $1 \% 0.33$ olarak bulunmuştur. Hastalık şiddeti 3 ile 6 arasında değişmiştir. Ortalama hastalık şiddeti 
ise 4 olarak bulunmuştur. $P$. striiformis hastalık etmeni 19 tarlada görülmüştür. $P$. striiformis hastalık etmeninin yaygınlığ $1 \% 1$ ile $\% 20$ arasında değişmiş, ortalama yaygınlığ $1 \% 4.59$ olarak bulunmuştur. Hastalık şiddeti 3 ile 7 arasında değişmiş, ortalama hastalık şiddeti 5.21 olarak bulunmuştur. P. recondita f. sp. tritici hastalık etmeni 13 tarlada görülmüştür. $P$. recondita f. sp. tritici hastalık etmeninin yaygınlığı $\% 1$ ile $\% 3$ arasında değişmiş, ortalama yaygınlığı \%0.66 olarak bulunmuştur. Hastalık şiddeti 3 ile 5 arasında değişmiş, ortalama hastalık şiddeti 3.69 olarak bulunmuştur. $P$. graminis f. sp. tritici hastalık etmeni 21 tarlada görülmüştür. Hastalık etmeninin yaygınlığ $1 \% 1$ ile $\% 20$ arasında değişmiş, ortalama yaygınlığ \%3.88 olarak bulunmuştur. Hastalık şiddeti 3 ile 7 arasında değişmiştir. Ortalama hastalık şiddeti ise 4.80 olarak bulunmuştur. Delice ilçesinde Septorya yaprak lekesi 12 tarlada görülmüştür. S. tritici hastalık etmeninin yaygınlı̆̆ $1 \% 1$ ile \%10 arasında değişmiş, ortalama yaygınlığ $1 \% 1.88$ olarak bulunmuştur. S. tritici'nin hastalık şiddeti 3 ile 6 arasında değişmiștir. Ortalama hastalık șiddeti 4.41 olarak bulunmuştur. Alternaria sp. hastalık etmeni ise 2 tarlada görülmüştür. Alternaria sp. hastalık etmeninin yaygınlığ 1 iki tarlada da \%2 olarak belirlenmiş, ortalama yaygınlığ $1 \% 0.14$ olarak bulunmuştur. Alternaria sp.'nin hastalık şiddeti iki tarlada da 4 olarak tespit edilmiştir.

Kırıkkale ilinin Sulakyurt ilçesinde yapılan sürvey çalışmasında, ilçenin arpa ekim alanını temsil edebilecek sayıda toplam 11 tarla gezilmiştir. Sulakyurt ilçesinde $D$. teres f. maculata hastalık etmeni 9 tarlada görülmüştür. D. teres f. maculata hastalık etmeninin yaygınlığı \%1 ile \%70 arasında değişmiş, ortalama yaygınlığı $\% 13.72$ olarak bulunmuştur. Hastalık şiddeti 3 ile 8 arasında değişmiş, ortalama hastalık şiddeti 4.66 olarak bulunmuştur. D. teres f. teres hastalık etmeni 3 tarlada görülmüştür. Bu hastalık etmeninin yaygınlığı \%2 ile \%50 arasında değișmiş, ortalama yaygınlığ $1 \% 5$ olarak bulunmuştur. Hastalık şiddeti 3 ile 8 arasında değişmiş, ortalama hastalık şiddeti 6 olarak bulunmuştur. D. graminea hastalık etmeni 2 tarlada görülmüsstür. $D$. graminea hastalık etmeninin yaygınlığı $\% 1$ olarak tespit edilmiş, ortalama yaygınlığ 1 ise $\% 0.18$ olarak bulunmuştur. Sulakyurt ilçesinde $R$. commune hastalık etmeni 11 tarlada görülmüştür. $R$. commune hastalık etmeninin yaygınlığ $\%$ 1 ile $\% 20$ arasında değişmiş, ortalama yaygınlığ $\% 3.45$ olarak bulunmuştur. Hastalığın şiddeti 3 ile 6 arasında değişmiş, ortalama hastalık şiddeti 3.81 olarak bulunmuştur. Külleme hastalığ 3 tarlada görülmüştür. E. graminis f. sp. hordei hastalık etmeninin yaygınlığ 3 tarlada da \%1 olarak tespit edilmiş, ortalama yaygınlığı ise \%0.27 olarak bulunmuştur. Hastalığın şiddeti 3 tarlada da 3 olarak tespit edilmiştir. Sulakyurt ilçesinde $P$. hordei hastalık etmeni 2 tarlada görülmüsşür. $P$. hordei hastalık etmeninin yaygınlığ iki tarlada da $\% 1$ olarak tespit edilmiş, ortalama yaygınlığ $1 \% 0.18$ olarak bulunmuştur. $P$. hordei'nin hastalık şiddeti 3 ile 4 arasında değişmiş, ortalama hastalık şiddeti 3.5 olarak bulunmuştur.

Kırıkkale ilinin Sulakyurt ilçesinde yapılan sürvey çalışmasında ilçenin buğday ekim alanını temsil edebilecek sayıda toplam 25 tarla gezilmiştir. Sulakyurt ilçesinde Külleme hastalığı 9 tarlada görülmüştür. E. graminis f. sp. tritici hastalık etmeninin 
yaygınlığ $\% 1$ ile \%3 olarak değişmiştir. E. graminis f. sp. tritici'nin ortalama yaygınlığ $1 \% 0.6$ olarak bulunmuştur. Hastalığın şiddeti 3 ile 4 arasında değişmiş, ortalama hastalık şiddeti 3.11 olarak bulunmuştur. $P$. striiformis hastalık etmeni 11 tarlada görülmüsstür. $P$. striiformis hastalık etmeninin yaygınlığ $1 \% 1$ ile $\% 20$ arasında değişmiş, ortalama yaygınlığ $\% 2.16$ olarak bulunmuştur. Hastalığın şiddeti 3 ile 8 arasında değişmiş, ortalama hastalık şiddeti 5.09 olarak bulunmuştur. P. recondita f. sp. tritici hastalık etmeni 2 tarlada görülmüsstür. P. recondita f. sp. tritici hastalık etmeninin yaygınlığ iki tarlada da \%1 olarak belirlenmiş, ortalama yaygınlığı ise $\% 0.08$ olarak bulunmuştur. Bu hastalığın şiddeti 3 ile 5 arasında değişmiş, ortalama hastalık şiddeti 4 olarak bulunmuştur. $P$. graminis f. sp. tritici hastalık etmeni 8 tarlada görülmüştür. Hastalık etmeninin yaygınlığ $\% 1$ ile \%20 arasında değişmiş, ortalama yaygınlı̆̆ $1 \% 1.56$ olarak bulunmuştur. P. graminis f. sp. tritici'nin hastalık şiddeti 3 ile 8 arasında değişmiş, ortalama hastalık şiddeti 5.87 olarak bulunmuştur. Sulakyurt ilçesinde Septorya yaprak lekesi 6 tarlada görülmüştür. S. tritici hastalık etmeninin yaygınlığı \%1 ile $\% 10$ arasında değişmiş, ortalama yaygınlığ $\% 0.72$ olarak bulunmuştur. Hastalığın şiddeti 3 ile 5 arasında değişmiş, ortalama hastalık şiddeti 3.83 olarak bulunmuştur. $P$. tritici-repentis hastalık etmeni 6 tarlada görülmüştür. $P$. tritici-repentis hastalık etmeninin yaygınlığı $\% 1$ ile $\% 5$ arasında değişmiş, ortalama yaygınlığı \%0.48 olarak bulunmuştur. Hastalık şiddeti 3 ile 5 arasında değişmiş, ortalama hastalık şiddeti ise 3.5 olarak bulunmuştur.

Kırıkkale ilinin Çelebi ilçesinde yapılan sürvey çalışmasında ilçenin arpa ekim alanını temsil edebilecek sayıda toplam 4 tarla gezilmiştir. Çelebi ilçesinde $D$. teres f. maculata hastalık etmeni 4 tarlada da görülmüştür. D. teres f. maculata hastalık etmeninin yaygınlığ $1 \% 1$ ile $\% 50$ arasında değişmiş, ortalama yaygınlı̆̆ ise \%13.5 olarak bulunmuştur. Hastalığın şiddeti 4 ile 6 arasında değişmiş, ortalama hastalık şiddeti 4.75 olarak bulunmuştur. $D$. teres f. teres hastalık etmeni 2 tarlada görülmüştür. $D$. teres f. teres hastalık etmeninin yaygınlığı iki tarlada da \%1 olarak tespit edilmiş, ortalama yaygınlığı $\% 0.5$ olarak bulunmuştur. Bu hastalığın şiddeti 4 ile 5 arasında değişmiş, ortalama hastalık şiddeti ise 4.5 olarak bulunmuştur. $D$. graminea hastalık etmeni 2 tarlada görülmüştür. D. graminea hastalık etmeninin yaygınlığ1 \%3 ile \%7 arasında değişmiş, ortalama yaygınlığ ise \%2.5 olarak bulunmuştur. Çelebi ilçesinde $R$. commune-hastalık etmeni 3 tarlada görülmüştür. R.commune hastalık etmeninin yaygınlığ $\% 3$ ile \%10 arasında değişmiş, ortalama yaygınlığ $1 \% 4.25$ olarak bulunmuştur. Hastalığın şiddeti 4 ile 8 arasında değişmiş, ortalama hastalık şiddeti 6 olarak bulunmuştur. Külleme hastalığı 2 tarlada görülmüştür. E. graminis f. sp. hordei hastalık etmeninin yaygınlığı bu tarlalarda \%1 ve $\% 2$ olarak bulunmuş, ortalama yaygınlığ 1 ise $\% 0.75$ olarak bulunmuştur. Hastalığın şiddeti iki tarlada da 3 olarak tespit edilmiştir.

Kırıkkale ilinin Çelebi ilçesinde yapılan sürvey çalışmasında ilçenin buğday ekim alanını temsil edebilecek sayıda toplam 11 tarla gezilmiştir. Çelebi ilçesinde Külleme hastalığı 3 tarlada görülmüştür. E. graminis f. sp. tritici hastalık etmeninin yaygınlığ $\% 1$ ile $\% 2$ arasında değişmiş, ortalama yaygınlığı ise $\% 0.45$ olarak bulunmuştur. Hastalığın şiddeti 3 tarlada da 3 olarak tespit edilmiştir. P. striiformis 
hastalık etmeni 9 tarlada görülmüştür. $P$. striiformis hastalık etmeninin yaygınlığ 1 $\% 1$ ile $\% 3$ arasında değişmiş, ortalama yaygınlığ $\% 1.18$ olarak bulunmuştur. Hastalığın şiddeti 3 ile 4 arasında değişmiş, ortalama hastalık şiddeti 3.55 olarak bulunmuştur. $P$. graminis f. sp. tritici hastalık etmeni 5 tarlada görülmüştür. Hastalık etmeninin yaygınlığ $1 \% 1$ ile $\% 2$ arasında değişmiş, ortalama yaygınlığ ise $\% 0.54$ olarak bulunmuştur. Hastalığın şiddeti 3 ile 6 arasında değişmiş, ortalama hastalık şiddeti ise 4.2 olarak bulunmuştur. Çelebi ilçesinde Septorya yaprak lekesi 6 tarlada görülmüştür. S. tritici hastalık etmeninin yaygınlığ $\% 1$ ile $\% 5$ arasında değişmiş, ortalama yaygınlığ $1 \% 0.90$ olarak bulunmuştur. Hastalık şiddeti 3 ile 6 arasında değişmiş, ortalama hastalık şiddeti 4 olarak bulunmuştur. Çelebi ilçesinde P. triticirepentis hastalık etmeni 1 tarlada görülmüştür. $P$. tritici-repentis hastalık etmeninin yaygınlığı \%1 olarak belirlenmiş, ortalama yaygınlığ $\% 0.09$ olarak bulunmuştur. Hastalığın şiddeti bu tarlada 3 olarak tespit edilmiştir.

Arpa yaprak hastalıklarından $D$. teres hastalık etmeninin iki formu da görülmüsstür. A $\breve{g}$ benek hastalığı nokta formu (D. teres f. maculata), Ağ benek hastalığ ağ formu (D. teres f. teres), Çizgili yaprak lekesi (D. graminea), Arpa yaprak lekesi ( $R$. commune), Külleme (E. graminis f. sp. hordei), Sarı pas (P. striiformis), Kahverengi pas (P. hordei) ve Kara pas ( $P$. graminis f. sp. tritici) arpa bitkilerinde görülmüştür. Belirlenen bu hastalıkların yaygınlıkları ortalama olarak $D$. teres f. maculata $\% 5.63$, $D$. teres f. teres \%1.77, D. graminea \%0.35, R. commune \%4.37, E. graminis f. sp. hordei $\% 0.53$, P. striiformis \%0.06, P. hordei $\% 0.47$, P. graminis f. sp. tritici $\% 0.03$ oranlarında bulunmuştur.

Buğday yaprak hastalıklarından Külleme (E. graminis f. sp. tritici), Sarı pas ( $P$. striiformis), Kahverengi pas ( $P$. recondita f. sp. tritici), Kara pas ( $P$. graminis f. sp. tritici), Septoria yaprak lekesi (S. tritici) ve yaprak lekesi meydana getiren $P$. triticirepentis ve Alternaria sp. belirlenmiştir. Belirlenen bu hastalıkların yaygınlıkları ortalama olarak E. graminis f. sp. tritici \%0.46, P. striiformis \%1.94, P. recondita f. sp. tritici \%0.20, P. graminis f. sp. tritici \%1.43, S. tritici \%1.35, P. tritici-repentis $\% 0.20$, Alternaria sp. $\% 0.09$ oranlarında bulunmuştur.

Konya, Karaman, Niğde ve Aksaray yörelerinde 1993 ve 1994 yıllarında yapılan bir çalışmada tahıllarda önemli hastalıkların durumu araştııılmıştır (Yıldırım ve ark. 1999). 1993 y1lında Konya ilinde incelenen 54 tarlanın 10'unda Arpa çizgili yaprak lekesi hastalığ (Drechslera graminea) ve 1'inde Arpa yaprak lekesi hastalığg (Rhynchosporium secalis=Rhynchosporium commune) bulunmuştur. 1994 y1lında Konya ilinde incelenen 94 tarlanın 18'inde Arpa çizgili yaprak lekesi hastalığı ve 1'inde Arpa yaprak lekesi hastalığı bulunmuştur. Karaman ilinde 1993 yılında incelenen 10 tarlada Arpa çizgili yaprak lekesi hastalığı ve Arpa yaprak lekesi hastalığına rastlanılmamıştır. Karaman ilinde 1994 yılında incelenen 19 tarlanın 2'sinde Arpa çizgili yaprak lekesi hastalığı bulunurken Arpa yaprak lekesi hastalığg tespit edilememiş̧ir. 
Niğde ilinde 1993 yılında incelenen 8 tarlada Arpa çizgili yaprak lekesi ve Arpa yaprak lekesi hastalıkları tespit edilememiştir. Niğde ilinde 1994 yılında incelenen 9 tarlanın 3'ünde Arpa çizgili yaprak lekesi hastalığı görülürken Arpa yaprak lekesi hastalığı tespit edilememiş̧ir. Aksaray ilinde 1993 yılında incelenen 5 tarlanın 1'inde Arpa çizgili yaprak lekesi hastalığı bulunurken Arpa yaprak lekesi hastalığı tespit edilememiştir. Aksaray ilinde 1994 yılında incelenen 17 tarlanın 2'sinde Arpa çizgili yaprak lekesi hastalığı görülmüş olup Arpa yaprak lekesi hastalığı tespit edilememiştir. Bizim çalışmalarımızda ise Arpa yaprak lekesi hastalığı $(R$. commune) incelenen toplam 128 tarlanın 117'sinde görülmüştür ve ortalama yaygınlığ $1 \% 4.37$ oranında bulunmuştur. Arpa çizgili yaprak lekesi hastalığı $(D$. graminea) ise incelenen 128 tarlanın 14'ünde görülmüştür ve ortalama yaygınlığ 1 $\% 0.35$ oranında bulunmuştur. Bizim çalışmalarımız ile karşılaştıııldığında Kırıkkale ilinde incelenen tarlalarda Arpa yaprak lekesi hastalığının Konya, Karaman, Niğde ve Aksaray illerine göre daha yüksek oranda olduğu görülmektedir.

Orta Anadolu Bölgesi'nde gerçekleştirilen bir çalışmada 1992 yılında 33 adet arpa tarlası incelenmiştir. D. graminea ile enfekteli 24 tarlanın 22'sinde \%1-10 oranlarında ve 2 tarlada ise $\% 20$ ve daha yüksek oranlarda hastalık tespit edilmiştir. 1993 yllında incelenen 35 arpa tarlasindan $D$. graminea ile enfekteli 19 tarlanın 12 'sinde \%1-10, 4 tarlada \%11-20 ve 3 tarlada ise \%20 ve üzeri yaygınlı oranında hastalık tespit edilmiştir (Mamluk ve ark. 1997). Bizim çalışmamızda ise D. graminea, incelenen 128 tarlanın 14'ünde ve ortalama \%0.35 oranında bulunmuştur.

Orta Anadolu Bölgesi'nde 1992 yılında Mamluk ve ark. (1997) tarafından yürütülen çalışmada $R$. secalis ( $R$. commune) ile enfekteli 7 tarlanın 5'inin \%1-10 ve 2'sinin ise \%11-20 yaygınlık oranlarında hastalık ile bulaşık olduğu bildirilmiştir. 1993 yılında aynı araştırıcılar tarafından gerçekleştirilen çalışmada ise $R$. commune ile enfekteli 15 tarlanın 6'sında \%1-10, 1'inde \%11-20 ve 8'inde ise \%20 ve üzeri yaygınlık oranında hastalık bulunduğu bildirilmiştir. Bizim çalışmamızda ise $R$. commune incelenen 128 tarlanın 117'sinde ve ortalama \%4.37 oranında bulunmuştur. Çalışmamızda $R$. commune patojeni incelenen tarlaların büyük bir çoğunluğunda görülmüştür.

Orta Anadolu Bölgesi'nde Mamluk ve ark. (1997) tarafindan 1992 y1lında yürütülen çalışmada E. graminis f. sp. hordei ile enfekteli 3 tarlanın 2'si \%1-10, 1'i ise \%20 ve üzeri yaygınlık oranında hastalık ile bulaşık olarak bulunmuştur. 1993 yılında aynı araştırıcılar tarafından gerçekleştirilen çalışmada ise E. graminis f. sp. hordei ile enfekteli 6 tarlanın 5'inde \%1-10 ve 1 tarlada ise $\% 20$ ve üzeri yaygınlık oranında hastalık bulunmuştur. Bizim çalışmalarımızda ise E. graminis f. sp. hordei incelenen 128 tarlanın 34'ünde ve ortalama \%0.53 oranında bulunmuştur.

Orta Anadolu Bölgesi'nde 1992 yilında Mamluk ve ark. (1997) tarafindan gerçekleştirilen çalışmada $P$. hordei görülmemiştir. 1993 yılında aynı araştırıcılar tarafından gerçekleştirilen çalışmada $P$. hordei ile enfekteli 5 tarla rapor edilmiştir. Bizim çalışmamızda ise $P$. hordei incelenen 128 tarlanın 28 'inde ve ortalama $\% 0.47$ oranında bulunmuştur. 
Orta Anadolu Bölgesi'nde 1992 yilında Mamluk ve ark. (1997) tarafindan gerçekleştirilen çalışmada arpa bitkilerinde $P$. graminis f. sp. tritici tespit edilememiştir. 1993 yılında aynı araştırıcılar tarafından gerçekleştirilen çalışmada $P$. graminis f. sp. tritici ile enfekteli bir tarla bulunmuştur. Bizim çalışmamızda ise $P$. graminis f. sp. tritici incelenen 128 arpa tarlasının 3'ünde ve ortalama \%0.03 oranında bulunmuştur.

Çelik ve Karakaya (2015) tarafından 2012 yılında Eskişehir ilinde yapılan çalışmada 121 arpa tarlası incelenmiştir. Bu çalışmada $D$. teres hastalık etmeni 114 tarlada görülmüş ve ortalama yaygınlık \%22.5 olarak bildirilmiştir. Hastalık etmeninin iki formu da (D. teres f. maculata ve $D$. teres f. teres) görülmüştür. Bizim çalışmamızda $D$. teres hastalık etmeninin her iki formu da tespit edilmiştir. D. teres f. maculata incelenen 128 arpa tarlasının 101'inde görülmüş ve ortalama yaygınlığı \%5.63 olarak bulunmuştur. $D$. teres f. teres incelenen 128 arpa tarlasının 59'unda görülmüş ve ortalama yaygınlığ $\% 1.77$ olarak bulunmuştur.

Kırıkkale ilinde Drechslera teres hastalık etmeninin çok fazla tarlada görüldüğü ancak yaygınlığının Eskiş̧ehir iline göre daha düşük oranda olduğu söylenebilir.

Çelik ve Karakaya (2015) tarafından 2012 yılında Eskişehir ilinde yapılan çalışmada Arpa çizgili yaprak lekesi hastalığ 1 (D. graminea) incelenen 121 tarlanın 59'unda görülmüş ve ortalama yaygınlığ $1 \% 1.75$ olarak rapor edilmiştir. Arpa yaprak lekesi hastalığ 1 (R. secalis $=R$. commune) ise incelenen 121 tarlanın 108 'inde görülmüş ve ortalama yaygınlığı \%22.07 olarak bildirilmiştir. Bizim çalışmamızda ise Arpa yaprak lekesi hastalığ (R. commune) incelenen toplam 128 arpa tarlasının 117'sinde görülmüş ve ortalama yaygınlığ $1 \% 4.37$ oranında bulunmuştur. Arpa çizgili yaprak lekesi hastalığı (D. graminea) ise incelenen 128 arpa tarlasının 14'ünde görülmüş ve ortalama yaygınlığ $\% 0.35$ oranında bulunmuştur.

Kırıkkale ilinde Arpa yaprak lekesi hastalığının (R. commune) çok fazla tarlada görüldüğü ancak yaygınlığının Eskişehir iline göre daha düşük seviyede olduğu söylenebilir. Arpa çizgili yaprak lekesi hastalığı (D. graminea) ise Eskişehir iline göre daha düşük oranda görülmüştür.

Çelik ve Karakaya (2015) tarafından 2012 yılında Eskişehir ilinde yürütülen çalışmada E. graminis f. sp. hordei incelenen 121 tarlanın 11'inde bulunmuş ve ortalama yaygınlığ $\% 0.45$ olarak bildirilmiştir. Bizim çalışmamızda ise E. graminis f. sp. hordei incelenen 128 arpa tarlasının 34 'ünde ve ortalama \%0.53 oranında bulunmuştur.

Çelik ve Karakaya (2015) tarafından 2012 yılında Eskişehir ilinde yürütülen çalışmada $P$. graminis f. sp. tritici incelenen 121 tarlanın 9'unda görülmüş ve ortalama yaygınlığ $1 \% 0.07$ olarak bildirilmiştir. P. hordei incelenen 121 tarlanın 33 'ünde görülmüş ve ortalama yaygınlığ $1 \% 5.93$ olarak rapor edilmiştir. Bizim çalışmamızda $P$. graminis f. sp. tritici incelenen 128 arpa tarlasının 3'ünde ve 
ortalama $\% 0.03$ oranında bulunmuştur. $P$. hordei hastalık etmeni ise incelenen 128 arpa tarlasının 28 'inde ve ortalama $\% 0.47$ oranında bulunmuştur.

Kırıkkale ilinde yürütülen çalışmamızda $D$. teres tarafından oluşturulan ağbenek hastalığının ve $R$. commune tarafından oluşturulan Arpa yaprak lekesi hastalığının arpada en yaygın hastalıklar olduğu görülmüsstür. $\mathrm{Bu}$ hastalıklar dünyada ve ülkemizde yaygın olarak görülen hastalıklardır (Mathre 1982, Aktaş 1997, Aktaş 2001, Akan ve ark. 2006, Karakaya ve ark. 2014). Ağbenek hastalığının iki formu da (D. teres f. maculata ve D. teres f. teres) sürveylerimiz sırasında Kırıkkale ilinde görülmüştür.

İren (1981) Türkiye'de buğdaylarda Tilletia caries ve Tilletia foetida tarafından meydana getirilen Sürme, Ustilago nuda tarafından meydana getirilen Açık rastık, $P$. striiformis, $P$. graminis f. sp. tritici ve $P$. recondita $f$. sp. tritici tarafından meydana getirilen pas hastalıkları, Septoria tritici tarafindan meydana getirilen yaprak yanıklığı, Fusarium spp., Drechslera sorokiniana, Pseudocercosporella herpotrichoides, Alternaria alternata, Sclerotium spp., Rhizoctonia spp. tarafindan meydana getirilen kök ve kök boğazı hastalıklarının önemli olduğunu belirtmiştir. Bu hastalıkların yanı sıra daha az önemli olarak E. graminis f. sp. tritici tarafından meydana getirilen Külleme, Tilletia controversa tarafindan meydana getirilen Cüce sürme, Urocystis tritici tarafindan meydana getirilen Sürme, Gaeumannomyces graminis tarafından meydana getirilen Göçerten hastalıklarının ve Buğday mozaik virüsünün de Türkiye'de görüldüğü bildirilmiştir. Bizim çalışmamızda da pas ve külleme hastalıklarına yaygın olarak rastlanılmıştır.

Finci (1982) Marmara Bölgesi’nde 1975 yılında yaptığı sürveylerde incelenen 548 buğday tarlasından 125 'inde Septorya hastalığını bulmuştur. Araştırıcı, incelenen tarlaların Bilecik'te \%2.0, Bolu'da \%17.8, Bursa'da \%11.6, Edirne'de \%30.6, İstanbul'da \%22.2, Kirklareli'nde \%28.3 ve Tekirdağ' da \%40.9' unda Septorya yaprak leke hastalığını rapor etmiştir. Kocaeli ve Sakarya illerinde hastalığa rastlanmamıştır. Aynı araştırıcının 1976 yılında yaptığı çalışmada ise yapılan sürveylerde toplam olarak incelenen 436 buğday tarlasından 40' inda Septorya yaprak leke hastalığına rastlanmıştır. Bilecik, Bursa, Bolu, Kocaeli, Sakarya'da o yıl hastalığa rastlanmamıştır. İncelenen tarlaların Edirne'de \%57.7, İstanbul'da \%2.8, Kırklareli'nde \%2.4 ve Tekirdağ'da \%39.8'inin Septorya yaprak leke hastalığ bulaşık olduğu tespit edilmiştir. Bizim çalışmamızda S. tritici incelenen 172 buğday tarlasının 72 'inde görülmüş olup hastalık yaygınlığ $1 \% 1.35$ olarak bulunmuştur. $\mathrm{Bu}$ sonuçlara bakılarak Kırıkkale ilinde $S$. tritici hastalığının görüldüğü tarla sayısının fazla olduğu ama hastalanan bitki sayısının az olduğu söylenebilir.

Mamluk ve ark. (1997) Orta Anadolu bölgesinde 1992 y1lında 108, 1993 y1lında 113 buğday tarlasını hastalıklar açısından incelemişlerdir. P. tritici- repentis iki yılda da birer tarlada görülmüştür. $\mathrm{Bu}$ etmen bizim çalışmamızda daha fazla tarlada görülmüştür. Aynı araştırıcılar yaprak lekesi oluşturan Alternaria türünü 1992 yılında 4 tarlada, 1993 yılında ise 5 tarlada tespit etmişlerdir. Alternaria sp. bizim çalışmamızda da sınırlı sayıda tarlada görülmüşsür. Bu çalışmada bulunan pas, 
külleme ve Septorya yaprak lekesi hastalıkları bizim çalışmamızda çok daha fazla sayıda tarlada bulunmuştur.

Kırıkkale ilinde incelenen arpa tarlalarında $D$. teres f. maculata hastalık etmeninin en yüksek görüldügü ilçeler Sulakyurt $(\% 13,72)$ ve Çelebi $(\% 13,5)$ ilçeleridir. Sulakyurt ilçesine bağlı Deredüzü köyünde $D$. teres f. maculata tarafindan meydana getirilen A $\breve{g}$ benek hastalığının nokta formu \%70 oranında, Çelebi ilçesine bağlı Yukarışeyh köyünde ise \%50 oranında görülmüştür. Bu iki ilçede sulanabilir arazilerin fazla olması hastalıklar için uygun ortam sağlayabilir. Ayrıca ekilen çeşidin hassasiyeti, fungusun virulent patotiplerinin olması da bu konuda etkili olabilir.

Kırıkkale ilinde $R$. commune hastalık etmeninin en yüksek oranda bulunduğu ilçe \%15,05 ile Keskin ilçesidir. Keskin ilçesinde arpa ekim alanı diğer ilçelere göre çok fazladır. Aynı tarlaya üst üste arpa ekimi bunun nedeni olabileceği gibi hassas çeşitlerin ekilmesi ve fungusun muhtemel virülent patotipleri bu durumda etkili olabilir.

D. graminea hastalık etmeni tarafından oluşturulan arpa çizgili yaprak lekesi hastalığ 1 düşük oranda görülmüştür. Yapılan tohum ilaçlamalarının ve sertifikalı tohum kullanılmasının hastalığın düşük oranda görülmesinde etkili olduğu düşünülmektedir.

Kırıkkale ilinde A $\breve{g}$ benek hastalığının ağ formu olan $D$. teres f. teres hastalık etmeninin yaygınlık oranı $\% 1,77$ olarak $D$. teres $\mathrm{f}$. maculata'dan daha düşük bir oranda çıkmıştır.

Külleme hastalığı (E. graminis f. sp. hordei), Sar1 pas (P. striiformis), Kahverengi pas ( $P$. hordei) ve Kara pas ( $P$. graminis f. sp. tritici) hastalık etmenlerinin yaygınlık oranları düşük çıkmıştır.

Kırıkkale ilinde incelenen buğday tarlalarında en yüksek hastalık oranı Sarı pas hastalığında \%4.59 ve Kara pas hastalığında \%3.88 ortalama ile Delice ilçesinde çıkmıştır.

S. tritici tarafından meydana getirilen Septorya yaprak lekesi hastalığının ise \%3.95 ile en yüksek ortalama yaygınlığı Keskin ilçesinde görülmüştür.

Kırıkkale ilinde incelenen buğday tarlalarında Külleme (E. graminis f. sp. tritici), Kahverengi pas ( $P$. recondita f. sp. tritici), P. tritici- repentis ve Alternaria sp. yaprak lekesi hastalıklarının yaygınlıkları daha düşük olarak bulunmuştur.

$\mathrm{Bu}$ çalışma ile Kırıkkale ilinde buğday ve arpa bitkilerinde görülen yaprak hastalıkları belirlenmiştir. Arpada ağ benek hastalığ ve Arpa yaprak lekesi hastalığ 1 en yaygın hastalıklar olarak görülmüştür. Buğdayda sarı pas, Kara pas ve Septorya yaprak lekesi en yaygın hastalıklar olarak görülmüştür. 
Yaygın olarak belirlenen hastalıklarla ilgili mücadele stratejileri geliştirilmelidir. Bunlar arasında kültürel tedbirler, sertifikalı tohumluk kullanımı ve dayanıklı çeşitlerin bulunup yetiştirilmesi önem kazanmaktadır.

\section{KAYNAKLAR}

Akan K., Çetin L., Albostan S., Düşünceli F. ve Mert Z. 2006. İç Anadolu'da görülen önemli tahıl ve nohut hastalıkları. Tarla Bitkileri Merkez Araştırma Enstitüsü Dergisi, 15 (12), 29-48.

Aktaş H. 1997. Untersuchungen Uber Die pysiologische Variationen von Dreschlera teres (Sacc.) Shoemaker an der Mittelanatolien angebauten Gersten und die Feststellung der Reaktionen der Gerstensorten gegen diesen Erreger. Journal of Turkish Phytopathology, 16, 53-65.

Aktaş H. 2001. Önemli hububat hastalıkları ve sürvey yöntemleri. T.C. Tarım ve Köyişleri Bakanlığı, Tarımsal Araştırmalar Genel Müdürlüğü, Bitki Sağlığı Araştırmaları Daire Başkanlığı, Ankara, 74 s..

Anonim 2010. Türkiye İstatistik Kurumu 2010 y1l $\quad$ verileri. http://www.tuik.gov.tr/bitkiselapp/bitkisel.zul.

Anonim 2013. www.tuik.gov.tr (Erişim tarihi: 01.12.2015).

Bockus W. W., Bowden R. L., Hunger R. M., Morrill W. L., Murray T. D. and Smiley R. W. (editörler). 2010. Compendium of wheat diseases and pests. 3rd ed. APS Press. Minnesota. $171 \mathrm{p}$.

Çelik E. ve Karakaya A. 2015. Eskiş̧ehir ili arpa ekim alanlarında görülen fungal yaprak ve başak hastalıklarının görülme sıklıklarının ve yoğunluklarının belirlenmesi. Bitki Koruma Bülteni, 55(2), 157-170.

Ellis M. B. 1971. Dematiaceous Hypomycetes. Commonwealth Mycological Institute, Kew, Surrey. England. 595 p.

Finci S. 1982. Marmara Bölgesinde buğday ekim alanlarında görülen Septoria fungusunun türleri, yayılışları ve çeşit reaksiyonları üzerinde çalışmalar. Bitki Koruma Bülteni, 22 (2), 72-88.

Geçit H. H., Çiftçi C. Y., Emeklier Y., İkincikarakaya S. Ü., Adak M. S., Kolsarıcı Ö., Ekiz H., Altınok S., Sancak C., Sevimay C. S. ve Kendir H. 2009. Tarla Bitkileri. Ankara Üniversitesi, Ziraat Fakültesi Yayınları, Yayın no: 1569, Ders Kitabı: 521.

İren S. 1981. Wheat diseases in Turkey. EPPO Bulletin, 11 (2), 47-52.

Karakaya A., Mert Z., Oğuz A. Ç., Azamparsa M. R., Çelik E., Akan K. and Çetin L. 2014. Current status of scald and net blotch diseases of barley in Turkey. IWBLD - 1st International Workshop on Barley Leaf Diseases, Salsomaggiore Terme, Italy, June 3-6, 2014.

Kün E. 1996. Tahıllar - I (Serin iklim Tahılları). Ankara Üniversitesi, Ziraat Fakültesi Yayınları, Yayın No: 1451, Ankara, 332 s. 
Mamluk O. F., Çetin L., Braun H. J., Bolat N., Bertschinger L., Makkouk K. M., Yıldırım A. F., Saari E. E., Zencirci N., Albustan S., Calı S., Beniwal S. P. S. and Düşünceli F. 1997. Current status of wheat and barley diseases in the Central Anatolia Plateau of Turkey. Phytopathologia Mediterranea, 36, 167-181.

Mathre D.E. (eds).1982. Compendium of barley diseases. APS Press, Minnesota, USA. 78 p.

Niks R. E., Dekens R. G. and Ommeren A. 1989. The abnormal morphology of a virulent Moroccan isolate belonging or related to Puccinia hordei. Plant Disease, 73, 28-31.

Özdemir H. Y., Karakaya A. ve Çelik Oğuz A. 2016. Kırıkkale ilinde buğday ve arpa bitkilerinde görülen yaprak hastalıkları. Türkiye VI. Bitki Koruma Kongresi Bildiri Özetleri Kitabı, 5-8 Eylül 2016, Konya, 776 s..

Saari E. E. and Prescott J. M. 1975. A scale for appraising the foliar intensity of wheat diseases. Plant Disease Reporter, 59, 77-380.

Yıldırım A. F., Kınacı E., Hekimhan H. ve Çeri S. 1999. Konya, Karaman, Niğde ve Aksaray yörelerinde tahıllarda önemli hastalıkların durumu ve bunlara dayanıklılık kaynaklarının araştırılması. Orta Anadolu'da Hububat Tarımının Sorunları ve Çözüm Yolları Sempozyumu, 8-11 Haziran 1999, Konya, 404-413.

Zaffarano P. L., McDonald B. A. and Linde C. C. 2011. Two new species of Rhynchosporium. Mycologia, 103 (1), 195-202. 